\title{
PENGARUH KARAKTERISTIK INDIVIDU TERHADAP EFEKTIVITAS KERJA PEGAWAI DINAS PEKERJAAN UMUM DAN PENATAAN RUANG PROVINSI LAMPUNG
}

\author{
Nina Arsanti ${ }^{(1)}$, Raditee Husin ${ }^{(2)}$, Sodirin ${ }^{(3)}$ \\ Fakultas Ekonomi Universitas Sang Bumi Ruwa Jurai \\ nina_arsantii@gmail.com,raditee.husin@fe.saburai.ac.id,sodirin@fe.saburai.ac.id
}

\begin{abstract}
Abstrak. Dalam rangka meningkatkan keproduktifan kerja berbagai cara harus ditempuh oleh organisasi agar pegawainya dapat bekerja secara baik dan benar, salah satu caranya dengan membentuk efektifitas bekerja kepada pegawai untuk mencapai tujuan yang ditetapkan. Efektifitas seseorang dalam bekerja akan menimbulkan efisiensi dalam melaksanakan pekerjaannya. Tujuan dari penelitian ini adalah, ingin mengetahui apakah ada pengaruh karakteristik individu terhadap efektifitas bekerja pegawai Di Dinas Pekerjaan Umum dan Penataan Ruang Provinsi Lampung. Hipotesis penelitian ini ada pengaruh Karakteristik Individu Terhadap Efektifitas Bekerja Pegawai Di Dinas Pekerjaan Umum dan Penataan Ruang Provinsi Lampung. Penelitian yang dilaksanakan jenis penelitian analitis, responden dalam penelitian ini berdasarkan data yang ada jumlah pegawai adalah 84 orang sehingga sampel atau responden yang digunakan adalah 84 orang. Hasil penelitian menunjukkan terdapat Pengaruh yang signifikan antara Karakteristik Individu (X) dengan Efektifitas Bekerja (Y), Karakteristik Individu mempunyai pengaruh positif terhadap Efektifitas Bekerja pegawai Kantor Dinas Pekerjaan Umum dan Penataan Ruang Provinsi Lampung. Hubungan Variabel terikat dan Variabel bebas dapat ditulis sebagai konstanta sebesar 23,783 berpengaruh positif terhadap koefisien regresi Karakteristik Individu (X) sebesar 0,339 ditambah error term.
\end{abstract}

Kata kunci: Efektivitas, Individu, Karakteristik, Kinerja.

\section{PENDAHULUAN}

Peranan sumber daya manusia dalam berorganisasi sangatlah penting karena sumberdaya manusia ini sebagai pengelola system, agar system ini tetap berjalan tentu dalam pengelolaannya harus memperhatikan aspek-aspek penting seperti pelatihan, pengembangan, dan efektifitas. Dalam hal ini sumber daya manusia dijadikan manejemen sebagai salah satu indikator penting pencapaian tujuan organisasi secara efektif dan vital.

Pengembangan sumber daya manusia pada dasarnya adalah peningkatan peningkatan kinerja pegawai yang mencerminkan kemampuan anggota organisasi dalam bekerja, artinya kinerja masing-masing pegawai dinilai dan diukur menurut kriteria yang sudah ditentukan sebelumnya oleh organisasi. Pada sisi inilah prestasi individu menjadi jaminan bagi organisasi bahwa organisasi akan tetap mampu menjawab setiap tantangan perubahan dan bahkan menjangkau setiap kemungkinan perubahaan pada masa yang akan datang. Untuk mencapai tujuan organisasi yaitu peningkatan kinerja kelembagaan sangat penting untuk memperhatikan beberapa faktor seperti komunikasi yang efektif, kompetensi dan efektifitas bekerja pegawai.

Penerapan otonomi daerah diharapkan menjadikan revitalisasi sangat penting artinya dalam rangka peningkatan kinerja birokrasi pemerintahan, penyediaan dan pelayanaan sehingga dapat memacu peningkatan efisiensi serta pemantapan daya saing. Berkaitan dengan hal tersebut, desentralisasi birokrasi pemerintahan, penyediaan dan pelayanan pada masyarakat secara nyata, efisien dan bertanggungjawab 
Hubungan kinerja dengan umur sangat erat kaitannya, alasannya adalah adanya keyakinan yang meluas bahwa kinerja merosot dengan meningkatnya usia. Pada pegawai yang berumur tua juga dianggap kurang luwes dan menolak teknologi baru. Namun di lain pihak ada sejumlah kualitas positif yang ada pada pegawai yang lebih tua, meliputi pengalaman, pertimbangan, etika kerja yang kuat, dan komitmen terhadap mutu (Robbins, 2011).

Tidak ada perbedaan yang konsisten antara pria dan wanita dalam kemampuan memecahkan masalah, ketrampilan analisis, dorongan kompetitif, motivasi, sosiabilitas, atau kemampuan belajar. Namun studi-studi psikologi telah menemukan bahwa wanita lebih bersedia untuk mematuhi wewenang, dan pria lebih agresif dan lebih besar kemungkinannya daripada wanita dalam memiliki pengharapan untuk sukses. Bukti yang konsisten juga menyatakan bahwa wanita mempunyai tingkat kemangkiran yang lebih tinggi daripada pria (Robbins, 2011).

Masa kerja ternyata konsisten berhubungan secara negatif dengan keluar masuknya pegawai dan kemangkiran, namun memiliki hubungan yang positif terhadap produktivitas kerja (Robbins, 2011). Masa kerja yang lama akan cenderung membuat seorang pegawai atau perawat lebih merasa betah dalam suatu organisasi, hal ini disebabkan diantaranya karena telah beradaptasi dengan lingkungannya yang cukup lama sehingga seorang pegawai akan merasa nyaman dengan pekerjaannya. Penyebab lain juga dikarenakan adanya kebijakan dari instansi atau organisasi mengenai jaminan hidup dihari tua (kreitner dan Kinicki, 2013).

Semakin tinggi tingkat pendidikan seseorang maka akan mempengaruhi pola pikir yang nantinya berdampak pada tingkat kepuasan kerja (Kreitner dan Kinicki, 2013). Pendapat lain juga menyebutkan bahwa semakin tinggi tingkat pendidikan maka tuntutan - tuntutan terhadap aspek - aspek kepuasan kerja di tempat kerjanya akan semakin meningkat (Wexley dan Yuki, 2013). Kutipan ini dapat dijelaskan bahwa tingkat pendidikan sesungguhnya akan berpengaruh positif terhadap kepuasan kerja dan kinerja seseorang.

Status perkawinan adalah ikatan lahir batin antara seorang pria dan seorang wanita sebagai suami istri dengan tujuan membentuk keluarga yang bahagia dan kekal berdasarkan Ketuhanan YME (Lembaga Demografi FE UI,2010:146). Berdasarkan pendapat Soerjono Soekanto dalam bukunya Kamus Sosiologi menyatakan bahwa kata perkawinan (marriage) adalah ikatan yang sah antara seorang pria dan wanita yang menimbulkan hak-hak dan kewajibankewajiban antara mereka maupun keturunannya. Salah satu riset menunjukkan bahwa pegawai yang menikah lebih sedikit absensinya, mengalami pergantian yang lebih rendah, dan lebih puas dengan pekerjaan mereka daripada rekan sekerjanya yang bujangan. Pernikahan memaksakan peningkatan tanggung jawab yang dapat membuat suatu pekerjaan yang tetap menjadi lebih berharga dan penting (Robbins, 2011).

\section{Efektifitas bekerja}

Efektivitas kerja adalah suatu keadaan dimana aktifitas jasmaniah dan rohaniah yang dilakukan oleh manusia dapat mencapaihasil akibat sesuai yang dikehendaki (Sutarto, 2017) . Sedangkan menurut Schermerhorn, (2017) Efektivitas kerja merupakan suatu ukuran tentang pencapaian suatu tugas atau tujuan .

Efektivitas menurut Bedjo Siswanto (2010) berarti menjalankan pekerjaan yang benar. Menurut kamus Administrasi 
perkantoran efektivitas berasal dari kata efektif yang berarti terjadinya suatu efek yang dikehendaki dalam suatu perbuatan (2011). Faktor-faktor Yang Mempengaruhi Efektivitas Kerja Ada empat faktor yang mempengaruhi efektivitas kerja, seperti yang dikemukakan oleh Richard M. Steers (2012), yaitu :

1. Karakteristik Organisasi

Karakteristik organisasi terdiri dari struktur dan tehnologi organisasi yang dapat mempengaruhi segi-segi tertentu dari efektivitas dengan berbagai cara. Yang dimaksud struktur adalah hubungan yang relatif tepat sifatnya, seperti dijumpai dalam organisasi, sehubungan dengan susunan sumber daya manusia struktur meliputi bagaimana cara organisasi menyusun orang-orangnya dalam menyelesaikan pekerjaan, sedangkan yang dimaksud tehnologi adalah mekanisme suatu organisasi umtuk mengubah masukan mentah menjadi keluaran.

\section{Karakteristik Lingkungan}

Lingkungan luar dan lingkungan dalam juga telah dinyatakan berpengaruh atas efektivitas, keberhasilan hubungan organisasi lingkungan tampaknya amat tergantung pada tingkat variabel kunci yaitu tingkat keterdugaan keadaan lingkungan, ketepatan persepsi atas keadaan lingkungan,tingkat rasionalisme organisasi. Ketiga faktor ini mempengaruhi ketepatan tanggapan organisasi terhadap perubahan lingkungan.

\section{Karakteristik Pekerja}

Pada kenyataannya para anggota organisasi merupakan faktor pengaruh yang paling penting karena perilaku merekalah yang dalam jangka panjang akan memperlancar atau merintangi tercapainya tujuan organisasi. Pekerja merupakan sumber daya yang langsung berhubungan dengan pengelolaan semua sumber daya yang ada di dalam organisasi, oleh sebab itu perilaku pekerja sangat berpengaruh terhadap pencapaian tujuan organisasi.

Pekerja merupakan modal utama di dalam organisasi yang akan berpengaruh besar terhadap efektivitas, karena walaupun tehnologi yang digunakan merupakan tehnologi yang canggih dan didukung oleh adanya struktur yang baik, namun tanpa adanya pekerja maka semua itu tidak ada gunanya.

4. Karakteristik Kebijaksanaan dan Praktek Manajemen.

Dengan makin rumitnya proses teknologi dan perkembangannya lingkungan maka peranan manajemen dalam mengkoordinasi orang dan proses demi keberhasilan organisasi semakin sulit.

\section{METODE PENELITIAN}

\section{Objek Penelitian}

Objek Penelitian dalam penelitian ini adalah pegawai Dinas Pekerjaan Umum dan Penataan Ruang Provinsi Lampung. Penelitian dilaksanakan pada rentang waktu April 2017 hingga Mei 2017.

\section{Metode dan Teknik Pengumpulan Data}

Dalam penelitian ini jenis data yang diperlakukan adalah :

\section{a. Data Primer}

Data primer merupakan data dasar yang akan diperoleh langsung tanpa perantara orang atau lembaga lain sebagai pihak ketiga. Data primer ini diperoleh dengan wawancara melalui responden dengan menggunakan daftar pertanyaan.

\section{b. Data Sekunder}

Data skunder merupakan data yang diperoleh melalui orang lain yang berhubungan dengan permasalahan yang dipecahkan. Data sekunder ini diperoleh melalui cara studi dokumenter yaitu 
mengumpulkan dan mempelajari brosurbrosur serta dokumen organisasi.

\section{Sampel dan Populasi}

Menurut Suharsimi Arikunto (2012) apabila objek penelitian kurang dari 100 maka lebih baik diambil semua, selanjutnya jika jumlah lebih dari 100 maka dapat diambil antara $10-15$ persen . Diketahui jumlah pegawai berjumlah 84 orang, sehingga responden dalam penelitian ini berjumlah 84 orang.

Kriteria Umum untuk skor yang dipergunakan daftar pertanyaan dalam penelitian ini adalah skala likert dengan skoring bernila 1,2,3,4,5 untuk jawaban pada setiap item pertanyaan .

\section{Metode Analisis Data}

Analisis kualitatif dilakukan dengan analisis tabel tunggal atau secara parsial yang akan menggambarkan kriteria masingmasing variabel yaitu kreteria variabel karakteristik individu dan efektifitas bekerja. Analisis kuantitatif yang dilakukan berdasarkan data primer yang diperoleh dari penyebaran instrument (daftar pertanyaan) kepada sampel, dan untuk mengetahui pengaruh dari variabel bebas (independent variable) terhadap variabel terikat (dependent variable).

Persamaan Regresi Linear Sederhana menentukan persamaan regresi linear sederhana untuk $\mathrm{X}$ :

$$
Y=a+b X+e
$$

Keterangan:

$$
\begin{aligned}
& \mathrm{Y}=\text { Efektivitas bekerja } \\
& \mathrm{a}=\text { Konstanta } \\
& \mathrm{b}=\text { Koefisien regresi } \mathrm{X} \\
& \mathrm{X}=\text { karakteristik individu } \\
& \mathrm{e}=\text { Faktor kesalahan }
\end{aligned}
$$

Untuk mengetahui besarnya pengaruh, penghitungan koefisien korelasi tersebut kemudian dilanjutkan dengan Rumus Koefisien Determinasi atau Koefisien Penentu (KP):

$$
K P=(r)^{2} x 100 \%
$$

Untuk menguji secara hipotesis secara parsial digunakan Uji t dengan rumus :

$$
t_{\text {hitung }}=\frac{r \sqrt{N-2}}{\sqrt{1-r^{2}}}
$$

Keterangan:

$$
\begin{array}{ll}
\mathrm{t}_{\text {hitung }} & =\text { Nilai } \mathrm{t} \\
\mathrm{r} & =\text { Koefisien Korelasi } \\
\mathrm{N} & =\text { Jumlah responden } \\
& \quad \text { (Sugiyono, 2008). }
\end{array}
$$

Kriteria untuk Uji $\mathrm{t}$ adalah sebagai berikut :

a) Jika $t_{\text {hitung }}>t_{\text {tabel }}$ maka Ha diterima dan Ho ditolak.

b) Jika $t_{\text {hitung }} \leq \mathrm{t}$ tabel maka Ha ditolak dan Ho diterima.

Taraf signifikan dalam penelitian ini digunakan $\alpha=0,05$ atau 5\%. Yang dimaksud dengan Hipotesis nol (Ho) dan Hipotesis alternatif (Ha) adalah :

Ho $=\mathrm{r} \leq 0=$ Berarti tidak ada pengaruh karakteristik individu terhadap efektivitas bekerja

$\mathrm{Ha}=\mathrm{r}>0=$ Berarti ada pengaruh karakteristik individu terhadap efektivitas bekerja.

\section{HASIL DAN PEMBAHASAN}

\section{Uji Validitas}

Validitas merupakan suatu kriteria yang dijadikan tolak ukur untuk menunjukkan tingkat kesahihan suatu alat pengukuran data yang dipergunakan. 
Pengujian kevalidan butir pertanyaan dilakukan dengan menggunakan koefisien nilai korelasi product moment dengan tingkat kepercayaan 95\%. Berdasarkan uji validitas yang dilakukan, memperlihatkan keseluruhan butir pertanyaan dinyatakan valid, sehingga dapat dipergunakan sebagai instrumen dalam penelitian selanjutnya.

\section{Uji Reliabilitas Data}

Pengujian realibilitas dilakukan untuk mengetahui daftar pertanyaan yang diajukan kepada responden apakah reliabel atau tidak. Dengan menggunakan rumus Alpha Cronbach , menurut sekaran (2002) reliabilitas kurang dari 0,6 adalah kurang baik sedangkan 0,7 dapat diterima dan diatas 0,8 adalah baik. Hasil analisis menunjukkan nilai Alpha Cronbach pada variabel X adalah 0,744 karena nilai Alpha Cronbach $\mathrm{X}$ diatas 0,6 maka dapat disimpulkan bahwa alat ukur dalam penelitian tersebut reliabel. Nilai Alpha Cronbach Y adalah 0,776 karena nilai Alpha Cronbach Y diatas 0,6 maka dapat disimpulkan bahwa alat ukur dalam penelitian tersebut reliabel. Maka dapat disimpulkan bahwa seluruh butir pertanyaan reliabel dan dapat dipergunakan sebagai instrumen dalam penelitian selanjutnya..

\section{Analisis Kuantitatif}

Berdasarkan hasil pengolahan data diketahui bahwa korelasi ( $\mathrm{R}$ ) antara variabel $\mathrm{X}$ dan $\mathrm{Y}$ adalah sebesar 0,429. Nilai ini memberikan arti bahwa variabel bebas (X), yang digunakan dalam model memiliki tingkat hubungan sebesar 42,9\% terhadap variabel $(\mathrm{Y})$. Sementara nilai $\mathrm{R}$ Square adalah sebesar 0,184 atau 18,4 persen. Hal ini berarti variabel Karakteristik Individu mampu menjelaskan sebesar 18,4 $\%$ terhadap variabel Efektifitas Bekerja dan $81,6 \%$ dijelaskan oleh variabel lain.
Mengacu hasil anova, diperoleh nilai $\mathrm{F}$ hitung 4,049. Nilai $F_{\text {tabel }}$ dengan $d k$ pembilang $\mathrm{k}=2$ dan $\mathrm{dk}$ penyebut $\mathrm{n}-\mathrm{k}-1=$ $84-2-1=83$, tingkat kepercayaan $95 \%$ $(\alpha=0,05)$ diperoleh nilai $F_{\text {tabel }}=3,27$, diperoleh nilai $F_{\text {hitung lebih besar }}$ dibandingkan dengan nilai $F_{\text {tabel }}$ maka Ho di tolak dan $\mathrm{Ha}$ di terima. Dapat disimpulkan bahwa model linier antara variabel Karakteristik Individu dan Efektifitas Bekerja signifikan.

Uji t menunjukkan bahwa koefisien $X$ (yaitu 0,339) berpengaruh terhadap $\mathrm{Y}$ seperti yang tercermin pada tingkat signifikan sebesar $0,049(<5 \%)$. Hubungan Variabel terikat dan Variabel bebas dapat ditulis dalam bentuk persamaan regresinya adalah $\mathrm{Y}=23,783+0,339 \mathrm{X}+$ et. Efektifitas Bekerja adalah konstanta sebesar 23,783 berpengaruh positif terhadap koefisien regresi Karakteristik Individu (X) sebesar 0, 339 ditambah error term.

Dari hasil pengolahan data tersebut telah berhasil dijawab permasalahan hipotesis yaitu ada pengaruh signifikan antara Karakteristik Individu (X) terhadap Efektifitas Bekerja (Y) pada Pegawai Kantor Dinas Pekerjaan Umum dan Penataan Ruang Provinsi Lampung. Hal ini dapat dilihat dari nilai $F_{\text {hitung }}$ yang diperoleh lebih besar dari nilai $F_{\text {tabel }}$ maka dapat disimpulkan bahwa variabel Karakteristik Individu (X) mempengaruhi Efektifitas Bekerja (Y) pegawai Kantor Dinas Pekerjaan Umum dan Penataan Ruang Provinsi Lampung, dari koefisien regresi yang positif pada variabel Karakteristik Individu (X) terhadap Efektifitas Bekerja (Y), dapat disimpulkan bahwa semakin baik Karakteristik Individu dan adanya Kompetensi yang baik, akan menimbulkan Efektifitas Bekerja yang semakin baik pula.

Pada uji hipotesis selain memperlihatkan pengaruh yang signifikan dari Karakteristik Individu terhadap Efektifitas Bekerja, memperlihatkan korelasi antara Karakteristik Individu dan 
Efektifitas Bekerja sebesar 0,429 X 100\% $=42,9 \%$. Hasil perhitungan juga memperlihatkan bahwa jika Efektifitas Bekerja naik sebesar satu skor maka Karakteristik Individu akan naik sebesar 0,339 yang dijelasakan dari persamaan regresi.

\section{KESIMPULAN DAN SARAN}

\section{Kesimpulan}

Berdasarkan hasil pengolahan data dapat disimpulkan bahwa terdapat Pengaruh yang signifikan antara Karakteristik Individu (X) dengan Efektifitas Bekerja (Y), Karakteristik Individu mempunyai pengaruh positif terhadap Efektifitas Bekerja pegawai Kantor Dinas Pekerjaan Umum dan Penataan Ruang Provinsi Lampung. Hubungan Variabel terikat dan Variabel bebas dapat ditulis dalam bentuk persamaan regresinya adalah $\mathrm{Y}=23,783+0,339 \mathrm{X}+$ et. Efektifitas Bekerja adalah konstanta sebesar 23,783 berpengaruh positif terhadap koefisien regresi Karakteristik Individu (X) sebesar 0, 339 ditambah error term.

\section{Saran}

Adapun saran yang diajukan peneliti adalah sebagai berikut:

1. Permasalahan yang terkait dengan output pekerjaan yang optimal akibat kebiasaan tersebut antara lain kebiasaan menunda pekerjaan, serta bekerja tanpa perencanan terlebih dahulu, hendaknya diatasi dengan langkah langkah sebagai berikut ; penentusan karakteristik pegawai yang diperkirakan akan mempengaruhi pelaksanaan tugas seperti penentuan latar belakang pendidikan, penentuan pengalaman bekerja serta mempertimbangkan penugasan pria untuk tugas tugas lapangan dikarenakan umumnya wanita tidak maksimal untuk tugas lapangan.

2. Hendaknya pimpinan organsiasi mengadakan evaluasi secara menyeluruh untuk mengukur tingkat efektifitas yang dimiliki pegawai sehingga dapat diukur tingkat hambatan yang ditemui pegawai dalam bekrja serta kemampuan bekerja secara efektif yang dimiliki masing masing pegawai.

\section{DAFTAR PUSTAKA}

Arikunto, Suharsimi. 2017. Prosedur Penelitian. Jakarta: Penerbit Rineka Cipta.

Flippo, Edwin B., dan Moh Masud. 2011. Manajemen Personalia. Jakarta: Erlangga.

Handoko, T. Hani. 2010. Manajemen Personalia dan Sumber Daya Manusia. Yogyakarta: Penerbit BPFE.

Hasibuan, Malayu. 2010. Manajemen Sumber Daya Manusia. Jakarta: PT.Bumi Aksara.

Kasim, Azhar. 2016. Pengukuran Efektifitas Organisasi. Jakarta: Penerbit BPFE UI.

Manullang, M. 2014. Dasar-Dasar Manajemen. Jakarta: Penerbit Ghalia Indonesia.

Nitisemito, Alex S. 2016. Manajemen Personalia. Jakarta: Penerbit Ghalia Indonesia.

Ranupandojo, Heidjrachman, dan Suad Husnan. 2013. Manajeman Personalia. Yogyakarta: Penerbit BPFE.

Siagian, Sondang P. 2013. Manajemen Sumberdaya Manusia. Jakarta: Pt.Bumi Aksara. 
Simanjuntak, Payaman J. 2017. Pengantar Ekonomi Sumber Daya Manusia. Jakarta: Penerbit Rineka Cipta.

Sinungan, Muchdarsyah. 2015. Produktivitas Apa dan Bagaimana. Jakarta: Pt.Bumi Aksara.

Stoner, Freeman, Gilbert Jr. 2016. Manajemen. Jakarta: PT.Prehallindo.

Sugiyono. 2008. Statistik Untuk Penelitian. Cetakan 4. Bandung: Alfabeta.

Umar, Husein. 2017. Metode Penelitian untuk Skripsi dan Tesis Bisnis. Jakarta: Penerbit PT. Raja Grafindo Persada. 